\title{
Failures related to the measurement of blood pressure among nursing students
}

\author{
Falhas relacionadas à mensuração da pressão arterial entre acadêmicos de enfermagem
}

Camylla Cavalcante Soares de Freitas ${ }^{1}$, Gabriela de Sousa Martins Melo ${ }^{1}$, Isabelle Katherinne Fernandes Costa ${ }^{1}$, Aline Maino Pergola-Marconato ${ }^{2}$, Manuela Pinto Tibúrcio ${ }^{1}$, Gilson de Vasconcelos Torres ${ }^{1}$

Objective: to identify failures related to the measurement of blood pressure among students of an undergraduate degree in nursing. Methods: this is an analytical, cross-sectional study conducted in skill lab simulated with 76 students, with the application of validated checklist, containing 28 key steps to assess the ability as the measurement of blood pressure in three blocks. To verify the association between the means of each failure, as the blocks by the time of stroke, Kruskal-Wallis, and the correlation Spearman was used. Results: in the three blocks, there were failures in steps: inadequacy in the selection of equipment needed; measuring the patient arm circumference; washing hands. The average failure was lower in the $5^{\text {th }}$ and largest in the $9^{\text {th }}$ period. Conclusion: there were positive correlations ranging from moderate to strong between initial observations $(\mathrm{p}=0.67)$ steps of the techniques $(\mathrm{p}=0.81)$ and closing remarks $(\mathrm{p}=0.43)$ of failures blood pressure period.

Descriptors: Students, Nursing; Teaching; Nursing; Blood Pressure Determination.

Objetivo: identificar falhas relacionadas à mensuração da pressão arterial entre acadêmicos de um curso de graduação em enfermagem. Métodos: estudo analítico, transversal, realizado em laboratório de habilidades simulado com 76 acadêmicos, com aplicação de lista de verificação validada, contendo os 28 passos fundamentais para avaliar a habilidade quanto à mensuração da pressão arterial em três blocos. Para verificar associação entre médias de cada falha, conforme os blocos por períodos do curso, utilizou-se Kruskall-Wallis e, a correlação, Spearman. Resultados: nos três blocos, observaram-se falhas nos passos: inadequação na seleção do material necessário; medição da circunferência do braço do cliente; não higienização das. A média de falhas foi menor no $5^{\circ}$ e maior no 9o período. Conclusão: observou-se correlações positivas variando entre moderado a forte entre observações iniciais $(\mathrm{p}=0,67)$ passos das técnicas $(\mathrm{p}=0,81)$ e observações finais $(\mathrm{p}=0,43)$ da quantidade de falhas da pressão arterial por período.

Descritores: Estudantes de Enfermagem; Ensino; Enfermagem; Determinação da Pressão Arterial.

\footnotetext{
${ }^{1}$ Universidade Federal do Rio Grande do Norte. Natal, RN, Brazil.

${ }^{2}$ Univesidade Estadual de Campinas, Campinas, SP, Brazil. 


\section{Introduction}

The blood pressure measurement should be performed in every health evaluation by appropriately trained professionals ${ }^{(1)}$. Due to its high prevalence and low rate control, hypertension becomes a major public health problem and one of the modifiable risk factors for cardiovascular events, and its primary prevention and early detection are the most effective ways to avoid it and priority targets for health professionals ${ }^{(1)}$.

The measuring technique must be performed properly for an adequate diagnosis. The recommended procedure is to explain the procedure; to make sure that the patient is not with a full bladder, did not practice physical exercise for at least 60 minutes, did not ingest of alcohol, coffee or food, or smoked in the previous 30 minutes; the patient should be in a sitting position, legs uncrossed, the arm should be at heart level; get the circumference of the arm; select the appropriate cuff size; put the cuff without leaving gaps, 2 to $3 \mathrm{~cm}$ above the cubital fossa; centering the middle of compression of the cuff over the brachial artery; estimate the level of systolic blood pressure by palpating the radial pulse; palpate the brachial artery in the cubital fossa and put the bell of the stethoscope without excessive compression; quickly inflate to exceed 20 to $30 \mathrm{mmHg}$ above the estimated level of systolic blood pressure; proceed slowly deflating (2 $\mathrm{mmHg}$ per second); determine the systolic pressure by the first sound auscultation (Korotkoff phase I); determine the diastolic pressure in the disappearance of sounds (phase V Korotkoff), listen about 20 to $30 \mathrm{mmHg}$ below the last sound to confirm its disappearance; inform the blood pressure values obtained for the patient; note the exact values arm in which blood pressure was measured ${ }^{(1)}$.

Thus, under the influence of the evolution of educational methodologies, skills training and construction of specific knowledge ${ }^{(2)}$, learning of blood pressure checking technique is a constant concern in the nursing teaching scenario, due to its presence in the daily routine of professional ${ }^{(3)}$.
Respecting the technical steps is essential to avoid failures that cause damage to the patient, and teaching and keeping students updated on the correct development of the blood pressure measurement procedure have been a challenge for teachers ${ }^{(3)}$.

In this context, the evaluation of academics throughout the subjects, understood as a potentially emancipatory institutional process is integral in the formation of the graduation process ${ }^{(4)}$.

A research of professionals in a hospital in North India revealed that in the technical aspect, only $2.2 \%$ of the professionals (only one nurse) performed the correct technique. When compared knowledge and technique, it was found that there was no correlation between them, being statistically insignificant $(\mathrm{p}=0.94)$. Thus, professionals with good knowledge still performed the technique inappropriately ${ }^{(5)}$.

In this sense, identifying the ability of academics in the blood pressure measurement procedure, and describing the most common failures in the development of this procedure is important to act more decisively to correct these weaknesses, aiming at higher quality care, given the importance of the blood pressure values as a key indicator of the health and cardiovascular morbidity predictor ${ }^{(6)}$.

Thus, this study aimed to identify gaps related to the measurement of blood pressure among students of an undergraduate nursing degree.

\section{Methods}

This is an analytical, cross-sectional study conducted from February to May 2014 in the Nursing Department of the Federal University of Rio Grande do Norte, RN, Brazil.

The population was 186 students enrolled in the first half of 2014, from the $5^{\text {th }}$ to $9^{\text {th }}$ period of the Nursing undergraduate course. The sample was selected by simple random sampling from a list, in alphabetical order, of all the scholars of each period. Among them, those listed with odd numbers $(n=76)$ were selected to develop the blood pressure 
measurement.

Inclusion criteria were: being a regularly enrolled student from the $5^{\text {th }}$ to the $9^{\text {th }}$ period of that course; have taken the course of Semiology and Semiotics of Nursing; be present at the Department of Nursing in the period of data collection.

For verification of skills, a simulated skills laboratory was built in the Department of Nursing, previously prepared to meet the research needs of suitable material and volunteers trained nurses to simulate the patient and respond to searched stimuli. It was chosen for actors informed not to induce any decision on the participant, since the procedure was not invasive, and allows greater reality to the simulation. Also, shooting for further evaluation of the procedure was performed.

The students were invited to participate, and when they did not accept there were a day and schedule for implementation of the procedure in the skills lab.

Data were obtained through the validated checklist $^{(7)}$ applied by nurses members of the Group of Nursing Procedures Incubator Research who assisted in the collection. The list includes the fundamental steps to assess the ability of the blood pressure measurement procedure, and it is structured in three blocks, totaling 28 steps, divided as follows: Block 1 - Initial observations (six): checking data in the patient's medical records; washing hands; selecting the necessary material; making disinfection of the hood and olive stethoscope; identifying the patient and explaining the procedure to be performed; investigating possible physiological and external conditions that may affect the measurement of blood pressure. Block 2 - technical steps: (18) keeping the patient at rest for 5 to 10 minutes if necessary; measuring the circumference of the patient's arm; positioning the patient; selecting the appropriate cuff; locating the brachial artery by palpation; placing the cuff selected in the arm; keeping the arm well supported at heart level; positioning the eyes at the same level of the mercury colu$\mathrm{mn}$ or aneroid gauge; estimating the level of systolic blood pressure; deflating the cuff quickly and waiting before starting the measure; placing the stethoscope ear; positioning the bell of the stethoscope over the brachial artery; rapidly inflating the cuff; slowly deflation; identifying the systolic pressure; identifying diastolic pressure; deflation of the cuff; performing further steps if necessary. Moreover, Block 3 - Final observations (four): analyzing the obtained value and informing the patient; organizing the environment; washing hands; recording the procedure in the record.

The evaluation of each of the items was through the classification in appropriate and inappropriate. In the case of inadequacies in the item, it must be justified and specified. The checklist contained an attachment with the criteria adopted to carry out the evaluation.

After the arrival of the participants to the skills lab, information was provided about the operation of the laboratory and handling of materials, requesting voluntary participation by signing the free informed consent and authorization for the use of images (videos and photos).

Before starting the procedure, the students received a fictitious medical record, containing a case with all the necessary information to guide them in providing care to the simulated patient. The participant was instructed to after the consultation of the medical record, start the procedure, and no further guidance was provided.

Data were entered into Microsoft Excel $®$ spreadsheet program and exported to statistical software, in which descriptive and inferential statistics were performed with $5.0 \%$ significance level. The association between the means of each failure according to the blocks by the course period, was verified by Kruskal-Wallis test, and for correlation, Spearman was applied by adopting the following classification: $\rho=$ to 0.39 (weak); $\rho=0.40$ to 0.69 (moderate); $\rho=0.70$ to 1 (strong) ${ }^{(8)}$.

The study complied with the formal requirements contained in the national and international regulatory standards for research involving human beings. 


\section{Results}

From 76 students observed, 16 (21.0\%) were in the $5^{\text {th }}$ period, $17(22.3 \%)$ in the $6^{\text {th }}, 13(17.1 \%)$ in the $7^{\text {th }}, 17(22.3 \%)$ in the $8^{\text {th }}$ and $13(171 \%)$ in the $9^{\text {th }}$ period. Out of the six steps that make up the Block 1 - initial observations, only for verification of the data records, there were no failures. However, the step of hand hygiene had a lower average failure (23.9\%), with an even distribution between periods.

Also in this initial block, the item of selecting the material obtained a higher average failures $(97.5 \%)$ in the periods. The $8^{\text {th }}$ period was highlighted despite having obtained high, inadequate values (88.2\%), it was the only period not totaling $100.0 \%$ of failures in this item (Table 1).
Regarding the failures in Block 2 - technical steps, there were $20(71.4 \%)$ out of 28 steps without failures. However, inadequacies of the patient's arm circumference is remarkable, considering that no students among all periods accomplished this step $(97.6 \%)$ or correctly carried out attempting to measurement, but inappropriately (11.7\%), totaling $100.0 \%$ of inadequacy at this stage. The step regarding the patients' position needs to be highlighted, where $35.6 \%$ of students did not perform it adequately.

The presentation of items of Block 3 - final observations stands out for inadequacy in the step of hand hygiene, with an average of $45.4 \%$, demonstrating that the procedure was not carried out mainly by $5^{\circ}$ and $7^{\circ}$ period students, respectively with $62.5 \%$ to $61.5 \%$. As the block of initial observations, only one step had no failures.

Table 1 - Percentage of failures in the stages of ability on the measurement of blood pressure of the three checklist blocks, in different periods of the course

\begin{tabular}{|c|c|c|c|c|c|c|}
\hline \multirow[b]{2}{*}{ Steps with failures } & \multicolumn{5}{|c|}{ Quantity of failures (\%) per period } & \multirow{2}{*}{$\begin{array}{c}\text { Total } \\
(n=76)\end{array}$} \\
\hline & $\begin{array}{c}5^{\circ} \\
(n=16)\end{array}$ & $\begin{array}{c}6^{\circ} \\
(n=17)\end{array}$ & $\begin{array}{c}7^{\circ} \\
(n=13)\end{array}$ & $\begin{array}{c}8^{\circ} \\
(n=17)\end{array}$ & $\begin{array}{c}9^{\circ} \\
(n=13)\end{array}$ & \\
\hline \multicolumn{7}{|l|}{ Block 1 - Initial observations } \\
\hline Selecting required material & 100 & 100 & 100 & 88.1 & 100 & 97.6 \\
\hline Performing disinfection hood and olive stethoscope & 50 & 47 & 23 & 52.9 & 46.1 & 43.8 \\
\hline $\begin{array}{l}\text { Investigating physiological and external conditions that may affect the } \\
\text { measurement of blood pressure }\end{array}$ & 25 & 58.8 & 15.3 & 23.5 & 46.1 & 33.7 \\
\hline Identifying and explaining the procedure to be performed & 37.5 & 11.7 & 7.6 & 29.4 & 53.8 & 28.0 \\
\hline Washing hands & 27 & 17,6 & 23 & 30.7 & 30.7 & 25.8 \\
\hline \multicolumn{7}{|l|}{ Block 2 - Technical steps } \\
\hline Measuring the arm circumference & 100 & 100 & 100 & 88.2 & 100 & 97.6 \\
\hline Placing the patient & 18.7 & 70.5 & 7.6 & 35.2 & 46.1 & 35.6 \\
\hline Keeping the patient at rest (5-10 minutes) & 18.7 & 47 & 7.6 & 29.4 & 30.7 & 26.6 \\
\hline Selecting the appropriate cuff & 31.2 & 23.5 & 53.8 & 17.6 & 23 & 29.8 \\
\hline Finding the brachial artery by palpation & 25 & 23.5 & 61.5 & 35.2 & - & 29.6 \\
\hline Deflating the cuff quickly and waiting before starting the measurement & 25 & 29.4 & 23 & 41.1 & 15.3 & 26.7 \\
\hline Estimating the level of systolic pressure & 6.2 & 5.8 & 30.7 & 35.5 & 23 & 20.2 \\
\hline Placing the stethoscope in the ear & 18.7 & 11.7 & 30.7 & 5.8 & 7.6 & 14.9 \\
\hline \multicolumn{7}{|l|}{ Block 3 - Final observations } \\
\hline Washing hands & 62.5 & 29.4 & 61.5 & 35.2 & 38.4 & 45.4 \\
\hline Registering the procedure in the medical records & 18.7 & - & - & 17.3 & 7.6 & 8.7 \\
\hline Interpreting the obtained value and informing the customer & 6.2 & - & - & - & - & 1.2 \\
\hline
\end{tabular}


The results of the failures in the blocks for the course periods are shown in Table 2. There was no significant difference between the failures committed between periods in each block and showing homogeneity between them.

Table 2 - Failures average distribution in the blocks of the blood pressure measurement procedure for periods of the course

\begin{tabular}{lcccc}
\hline \multirow{2}{*}{ Periods } & $\begin{array}{c}\text { Block 1 - Initial } \\
\text { Observations }\end{array}$ & $\begin{array}{c}\text { Block 2 - } \\
\text { Technical step }\end{array}$ & $\begin{array}{c}\text { Block 3 - Final } \\
\text { observations }\end{array}$ & Total \\
\cline { 2 - 5 } & Average (SD) & Average (SD) & Average (SD) & Average (SD) \\
\hline Fifth & $2,44(1,03)$ & $2,50(1,67)$ & $0,88(0,80)$ & $5,81(2,42)$ \\
Sixth & $2,47(0,93)$ & $3,35(1,32)$ & $0,29(0,47)$ & $6,12(1,93)$ \\
Seventh & $1,69(0,94)$ & $3,62(1,50)$ & $0,62(0,50)$ & $5,92(2,39)$ \\
Eighth & $2,18(0,88)$ & $3,18(1,55)$ & $0,53(0,62)$ & $5,88(2,28)$ \\
Ninth & $2,77(1,01)$ & $3,00(1,68)$ & $0,46(0,66)$ & $6,23(2,68)$ \\
p-value* & 0,06 & 0,20 & 0,17 & 0,94 \\
\hline *Kruskall Wallis test & & &
\end{tabular}

As for the Spearman correlation coefficients between the failures of the procedure blocks and periods, there was moderate to strong correlation between failures, with more strong correlation in Block 2 - technical steps. In general, the average failure was low (5.99), with a minimum of one and maximum of 13 steps with failures, since it was analyzed the total of 28 steps.

All blocks have influenced the overall error, block 2 - the technical steps (positive correlation $\rho=0.81$, strong and significant $p<0.01$ ) was the largest contributor to the overall error, followed by opening remarks (positive correlation $\rho=0.67$, strong and significant $\mathrm{p}<0.01$ ) and concluding observations (positive correlation $\rho=0.43$, moderate and significant $\mathrm{p}<0.01$ ).

When checking the correlation between the three blocks of the measurement of blood pressure, it was found positive, the low and significant correlation between the initial observations and the technical steps.

\section{Discussion}

Despite all the evidence showing the importance of hands in the chain of transmission of nosocomial infections, it is observed in practice, the low adherence to this technique by professionals ${ }^{(9)}$. This result is not similar to the result found in this study about the students since washing hands obtained average low failure $(23.9 \%)$.

However, although showing adequate results, not knowing the importance of this adherence as student implying higher risks related to professional care $^{(10)}$, being fundamental to emphasize and encourage such knowledge to students and trace the deficiencies in hygiene, as the first step in the development and implementation of measures to encourage this practice ${ }^{(11)}$.

In this case, not only the adherence is interesting, but the execution correctly should be emphasized in health care training courses ${ }^{(12)}$. Adding to this, research shows evidence of the impact of knowledge on the use of the practice ${ }^{(10)}$ justified only by studies which show the development of the art, excluding the precision of execution ${ }^{(13)}$.

The use of sphygmomanometer with cuff size out of the recommendations involves imprecision of the results obtained in the measurement of blood pressure may occur overestimated or underestimated values ${ }^{(14)}$, as a result of negligence on the measurement of arm circumference, as shown by the results of this study with the step of higher failure percentage of all three blocks (97.6\%).

The step of the hood disinfection and stethoscope olives obtained high-value failures or not being performed or completed. An integrative review found that $91.3 \%$ of the diaphragms of stethoscopes surveyed showed infectious agents reservoir, suggesting to disinfect them with alcohol to $70.0 \%$ before the procedure to minimize the risk of infection ${ }^{(15)}$.

The patient positioning during the measurement of blood pressure should be seated, with the lower arm extension and relaxation of the arm with the 
support pillow, and leaning back in his chair, legs uncrossed and feet flat on the floor, arm should be located at heart level, uncovered, supported with the palm facing up and elbow slightly flexed ${ }^{(1,16)}$.

With similar results to the study, 110 health professionals were evaluated for proper cuff selection after measuring the arm circumference and demonstrated that the percentage of correct answers was $\operatorname{nil}^{(17)}$.

As for the location of the brachial artery by palpation, the palpation of the brachial artery should perform in the cubital fossa before placing the bell or stethoscope diaphragm, which was not carried out by the participants, highlighting the $7^{\text {th }}$ period with high failure measure in this $\mathrm{step}^{(1)}$. As the cross-sectional study conducted in Rio Grande do Sul Cardiology Institute, Brazil, with 110 surveyed people, 42.1\% were also liabilities of failure at this stage ${ }^{(18)}$.

In thestep ofdeflating the cuffquicklyand waiting before starting the measurement, the inadequacy had more emphasis on the $7^{\text {th }}$ and $8^{\text {th }}$ periods because when starting the measurement immediately, they did not comply with the recommendations of the Brazilian Society of Cardiology, which suggests waiting around a minute to a new measure ${ }^{(1)}$.

When assessing the gaps between the blocks, the average value for the total analysis in the seventh period was 5.92. However, the errors were homogeneous among the five periods.

It was observed that the average failure was lower in the $5^{\text {th }}$ and greater in the $9^{\text {th }}$ period, which may be a reflection of the distance between theory and practice, and the routine procedure. However, there was no significant difference between the periods.

An answer to these high scores as the mismatching occurs by gaps between theory and practice that can interfere with the development of skill, suggesting the need for evaluation strategies in the procedure and continuing education between periods $s^{(18)}$ and can be identified as error on the graduate courses in inadequate training of future professionals for the procedure ${ }^{(19)}$.

There was a positive correlation observed in all three technical blocks, being the strongest correlation between failures in the technical steps $(p=0.20)$, indicating that the pedagogical practice needs to seek alternative ways to instigate the student's interest in developing a synthesis of knowledge ${ }^{(20)}$.

It is necessary to work the evaluation process throughout the course as well as the development of monitoring strategies in the formation of this ability, despite the great use of blood pressure measurement not only at the undergraduate and professional practice.

With the identification of weaknesses, the inadequacies can be minimized, and the points of disability can be reviewed ensuring to improve education, seeking to ensure effective practice associated with the theoretical basis.

The stress presented by the students during the procedure may have influenced the development and consequently increasing the occurrence of failures. As study limitation, there is the cross-sectional design of the study, with participants from a single university, which makes generalizations, but points out the need for further research on the subject in the same place and others, enabling the exchange of knowledge and enhancing the correction of failures.

Furthermore, it is understood that the stress suffered by students during the evaluation of this ability may be a bias in the study.

\section{Conclusion}

The inadequacy in the selection of the necessary material, the incorrect measurement of the patients' arm circumference, the absence of hand hygiene after the procedure are highlighted among the main problems related to the measurement of blood pressure.

There was a positive correlation in all steps, pointing out that all stages influenced for the error, 
with moderate to strong correlation between failures, with more strong correlation in Block 2 - technical steps. However, a positive, weak and significant correlation between the initial comments and technical steps were identified among the three blocks of the measurement of blood pressure.

\section{Acknowledgement}

Research funded by the Ministry of Science, Technology and Innovation Notice and the National Council of Scientific and Technological Development - Universal 14/2012.

\section{Collaborations}

Freitas CCS and Tibúrcio MP contributed to the data collection, organization and interpretation, writing and review of the article. Melo GSM and Torres GV contributed to the project design, analysis and interpretation of data and writing and review of the article. Costa IKF and Pergola-Marconato AM contributed to the writing and relevant critical review of the article content and approval of the final version to be published.

\section{References}

1. Sociedade Brasileira de Cardiologia, Sociedade Brasileira de Hipertensão, Sociedade Brasileira de Nefrologia. VI Diretrizes Brasileiras de Hipertensão. Arq Bras Cardiol. 2010; $95(1$ suppl.1):1-51.

2. Oliveira MFL, Neto Brandão W, Silva ARS, Veríssimo AVR, Cavalcante AMTS, Monteiro EMLM. Perceptions of students on the physical exams in clinical nursing practice. Rev Rene. 2016; 17(2):268-77.

3. Alavarce DC, Pierin AMG. Development of educational hypermedia to teach an arterial blood pressure measurement procedure. Rev Esc Enferm USP. 2011; 45(4):939-44.
4. Bittencourt HR, Creutzberg M, Rodrigues ACM, Csartelli AO, Freitas ALS. Desenvolvimento e avaliação de um instrumento para avaliação de disciplinas na educação superior. Est Aval Educ. 2011; 22(48):91-114.

5. Mohan B, Aslam N, Ralhan U, Sharma S, Gupta N, Singh VP, et al. Office blood pressure measurement practices among community health providers (medical and paramedical) in northern district of India. Indian Heart J. 2014; 66(4):401-7.

6. Amoore JN. Oscillometric sphygmomanometers: a critical appraisal of current technology. Blood Press Monit. 2012; 17(2):80-8.

7. Tibúrcio MP, Melo GSM, Balduíno LSC, Costa IKF, Dias TYAF, Torres GV. Validação de instrumento para avaliação da habilidade de mensuração da pressão arterial. Rev Bras Enferm. 2012; 7(4):5817.

8. Mello CB, Argollo NS, Beatriz PM, Abreu N, Godinho KD, Paula V et al. Abbreviated version do WISC-III: correlation between estimated IQ and global IQ of Brazilian children. Psic Teor Pesq. 2011; 27(2):149-55.

9. World Health Organization. WHO guidelines on hand hygiene in health care. First global patient safety challenge clean care is safer care. Geneva: WHO; 2007.

10. Van De Mortel TF, Kermode S, Progano T, Sansoni J. A comparison of the hand hygiene knowledge, beliefs and practices of Italian nursing and medical students. J Adv Nurs. 2012; 68(3):569-79.

11. Melo GSM, Tibúrcio MP, Freitas CCS, Liberato SMD, Mendes CKTT, Torres GV. Instrumento para avaliação da habilidade técnica e do conhecimento sobre higienização das mãos. Rev Bras Pesq Saúde. 2012; 15(3):91-102.

12. Tipple AFV, Sá AS, Mendonça KM, Sousa ACS, Santos SLV. Técnica de higienização simples das mãos: a prática entre acadêmicos da enfermagem. Cienc Enferm. 2010; 16(1):49-58.

13. Gordon CJ, Frotjold A, Fethney J, Green J, Hardy J, Maw M, et al. The Effectiveness of SimulationBased Blood Pressure Training in Preregistration Nursing Students. Simul Healthc. 2013; 8(5):33540 . 
14. Freitas CCQ, Pantarotto RFR, Costa LRLG. Relação circunferência braquial e tamanho de manguito utilizados nas Unidades Básicas de Saúde de uma cidade no interior paulista. J Health Sci Inst. 2013; 31(3):48-52.

15. Ferreira AM, Barcelos LS, Rigotti MA, Andrade D, Andreotti JT, Almeida MG. Areas of hospital environment: a possible underestimated microbes reservoir? - integrative review. Rev Enferm UFPE online [internet]. 2013 [cited 2014 Sept 20]; 7(esp):4171-82. Available from: http://www. revista.ufpe.br/revistaenfermagem/index.php/ revista/article/view/3498/pdf_2609

16. Imai Y. Clinical significance of home blood pressure and its possible practical application. Clin Exp Nephrol. 2014; 18(1):24-40.
17. Boll LFC, Irigoyen MC, Goldmeier. Brazilian guidelines for arterial hypertension: the reality of nursing in specialty hospital. Acta Paul Enferm. 2012; 25(5):775-80.

18. Almeida TCF, Lamas JLT. Nurses of adult intensive care unit: evaluation about direct and indirect blood pressure measurent. Rev Esc Enferm USP. 2013; 47(2):364-71.

19. Ribeiro CCM, Lamas JLT. Comparação entre as técnicas de mensuração da pressão arterial em um e em dois tempos. Rev Bras Enferm. 2012; 65(4):630-6.

20. Galvão ECF, Puschel VAA. Multimedia application in mobile plataforma forteaching the measurement of central venous pressure. Rev Esc Enferm USP. 2012; 46(n.esp):107-15. 